\title{
Processes in crystal mushes under fast-spreading mid-ocean Ridges
}

\author{
JÜRGEN KOEPKE ${ }^{1}$, DOMINIC MOCK ${ }^{1}$, CHAO ZHANG ${ }^{2,1}$ \\ ${ }^{1}$ Institut für Mineralogie, Leibniz Universität Hannover \\ ${ }^{2}$ State Key Laboratory of Continental Dynamics, Department \\ of Geology, Northwest University, Xi'an, China
}

Details on the accretion of the lower oceanic crust under fast-spreading mid-ocean ridges by crystal mushes, which are accumulated minerals from parental MORB's, are not known up to now. According to prominent end member models for ocean crust accretion, these mushes crystallized either in-situ in the deep crust (sheeted sill model) or in the shallow axial melt lens below the sheeted dikes, from which crystal mushes are subsiding into the deeper parts of the crust (gabbro glacier model). New results on investigations within the layered gabbro sequence from the Oman ophiolite, which is the largest and best-exposed fragment of fossil oceanic crust on land, may help to constrain the mechanism of deep crustal accretion, including the enigmatic process of layer formation.

We studied $\mathrm{a} \sim 3 \mathrm{~m}$ profile from a layered gabbro from the middle part of the lower crust showing dmscale layering (Wadi Somerah, Sumail block) with a high local resolution. We applied a multi-method approach of combining field, petrographic, geochemical, and microstructural observations in the same samples. Results indicate moderate cooling rates (Ca in Olivine, $1.2^{\circ} \mathrm{C} / \mathrm{kyr}$ to $22^{\circ} \mathrm{C} / \mathrm{kyr}$ ) and correlated variations in mineral compositions (major and trace elements), crystallization temperatures (estimated from REE data) and microstructural properties (EBSD). We see clear evidence that the dm-scale layering was formed by periodic density currents of crystal-laden magma within a sill environment, thus implying in situ crystallizing as mode of crystallization, of a melt, which show also signs of replenishment.

A requirement for in-situ crystallization is a substantial hydrothermal cooling of the deep crust in order to remove the latent heat of crystallization. We believe that this is facilitated by hydrothermal fault zones cutting the layered gabbro at many places. These are characterized by pervasive hydrothermal alteration and include also remnants of an initial hightemperature, mgmatic stage, implied by the presence of magmatic, chlorine-rich amphibole, as well as the record of hydrous partial melting of the host gabbros. 